\title{
Schistosoma mansoni Sambon, 1907: Morphometric Differences between Adult Worms from Sympatric Rodent and Human Isolates
}

\author{
Renata Heisler Neves/ ${ }^{++}$, Mário José dos Santos Pereira, \\ Regina Maria Figueiredo de Oliveira*, Delir Corrêa Gomes**/+++, \\ José Roberto Machado-Silva*/+
}

\begin{abstract}
Departamento de Anatomia Humana, Instituto de Biologia *Departamento de Patologia e Laboratórios, Faculdade de Ciências Médicas, UERJ, Av. 28 de Setembro 87 fundos, 1이으 andar, 20551-030

Rio de Janeiro, RJ, Brasil ** Laboratório de Helmintos Parasitos de Vertebrados, Departamento de Helmintologia, Instituto Oswaldo Cruz, Av. Brasil 4365, 21045-900 Rio de Janeiro, RJ, Brasil
\end{abstract}

A computer software for image analysis (IMAGE PRO PLUS, MEDIA CYBERNETICS) was utilized in male and females adult worms, aiming the morphological characterization of Schistosoma mansoni samples isolated from a slyvatic rodent, Nectomys squamipes, and humans in Sumidouro, Rio de Janeiro, Brazil and recovered from Mus musculus $\mathrm{C} 3 \mathrm{H} / \mathrm{He}$. The following characters for males's testicular lobes were analyzed: number, area, density, larger and smaller diameter, longer and shorter axis and perimeter and extension; for females: area, longer and shorter axis, larger and smaller diameter and perimeter of the eggs and spine; oral and ventral suckers area and distance between them in both sex were determined. By the analysis of variance (one way ANOVA) significant differences $(p<0.05)$ were observed in all studied characters, except for the density of testicular lobes. Significant differences $(p<0.05)$ were detected for all characters in the female worms. Data ratify that sympatric isolates present phenotypic differences and the adult female characters are useful for the proper identification of $\mathrm{S}$. mansoni isolates.

Key words: Schistosoma mansoni - morphology - isolates - Nectomys squamipes - C3H/He mice

In the nineties, molecular genotipic studies perfomed in Schistosoma mansoni have demonstrated molecular variations in this species (Barral et al. 1993, Dias Neto et al. 1993, McManus \& Hope 1993, Pillay \& Pillay 1994). Such observations are in agreement with preceeding morphological and biological studies providing the existence of intraspecific variations (strains) (Saoud 1965, Magalhães \& Carvalho 1973, Frandsen 1979, Paraense \& Corrêa 1981). More recently, we have showed that adult worm length is the only difference between sympatric isolates from rodent and human (Machado-Silva et al. 1994). The present study aims to define certain morphological characters of male and female adult worms to distinguish different isolates (rodent and human) of $S$. mansoni.

\footnotetext{
${ }^{+}$Corresponding author. Fax: +55-21-587.6112. E-mail: machado@uerj.br

++ Bolsista de Iniciação Científica-UERJ.

${ }^{+++} \mathrm{CNPq}$ research fellow, proc. no. 303.124/89-0.

Received 4 May 1998

Accepted 31 August 1998
}

\section{MATERIALS AND METHODS}

Experimental infection and studied worms - A total of 37 inbred $(\mathrm{C} 3 \mathrm{H} / \mathrm{He})$ Mus musculus L., seven days old, were infected by percutaneous route, with a rodent $(\mathrm{R})$ or a human samples $(\mathrm{H})$ isolated in Sumidouro District, State of Rio de Janeiro, Brazil. Each animal was exposed to 50 cercariae ( $\mathrm{R}$ or $\mathrm{H}$ isolate). The source, isolation and staining conditions were described elsewhere (Machado-Silva et al. 1994). Studied worms resulted from the first passage of the isolate under laboratory conditions (Machado-Silva et al. 1995).

Morphological analysis - A computer software for image analysis (IMAGE PRO PLUS, MEDIA CYBERNETICS) was utilized. For male the following features were considered: testicular lobes (number, area, density, larger and smaller diameter, longer and shorter axis, perimeter and extension). Female worms: egg and spine (area, longer and shorter axis, larger and smaller diameter and perimeter). For both sex, oral and ventral suckers area and distance between them were determined. Measurements are in micrometers, unless otherwise indicated.

Statistical analysis - One-way Analyse of Variance (ANOVA) was perfomed, considering as sig- 
nificative differences values of $\mathrm{p} £ 0.05$ (Vieira 1991).

\section{RESULTS}

The morphometric data of male worms are given in Table I. For all variables, $\mathrm{H}$ isolate showed higher values than the other except to the number of lobes. In relation to the testicular lobes, several characters had significant differences $(\mathrm{p}<0.05)$ except number, density and smaller diameter. Measurements regarding the suckers had not significant differences ( $p>0.05)$ in both isolates.
Supernumerary testicular lobes were present in both isolates: $\mathrm{R}(12 \%)$ and $\mathrm{H}(2 \%)$. Sometimes, not one but two (H isolate), or eventually even more (six) ( $\mathrm{R}$ isolate) were evident. The distance between the supernumerary testes and the last testicular lobe in the normal set, varied from $132.17 \mathrm{~mm}$ (H isolate) to $1251.80 \mathrm{~mm}$ ( $\mathrm{R}$ isolate)

Absence of egg in the uterus occured only in $6 \%$ of the females analyzed. None specimen showed more than one egg in the uterus. $\mathrm{R}$ isolate showed higher values for all measurements, presenting significative differences $(\mathrm{p}<0.05)$ (Table II).

TABLE I

Morphometric data (mean and standard deviation) of adult male worms of Schistosoma mansoni isolated from Nectomys squamipes ( $\mathrm{R}$ isolate) and humans (H isolate). Significant differences ( $\mathrm{p} £ 0.05)$

\begin{tabular}{|c|c|c|}
\hline \multirow[t]{2}{*}{ Character } & \multicolumn{2}{|c|}{ Isolates } \\
\hline & $H(n=54)$ & $\mathrm{R}(\mathrm{n}=50)$ \\
\hline \multicolumn{3}{|l|}{ Testicular lobes } \\
\hline number (ns) & $8.1 \pm 1.3$ & $7.8 \pm 1.4$ \\
\hline $\operatorname{area}^{a}$ & $43278 \pm 9931$ & $34225 \pm 8398$ \\
\hline density (ns) & $91 \pm 18$ & $88 \pm 21$ \\
\hline perimeter ${ }^{a}$ & $1076 \pm 187$ & $972 \pm 176$ \\
\hline smaller axis $a$ & $121 \pm 16$ & $107 \pm 14$ \\
\hline longer axis $a$ & $468 \pm 92$ & $421 \pm 90$ \\
\hline smaller diameter (ns) & $105 \pm 17$ & $91 \pm 18$ \\
\hline larger diameter ${ }^{a}$ & $435 \pm 82$ & $391 \pm 79$ \\
\hline \multicolumn{3}{|l|}{ Suckers area } \\
\hline oral (ns) & $22950 \pm 8673$ & $21959 \pm 6903$ \\
\hline ventral (ns) & $28906 \pm 7938$ & $28716 \pm 7430$ \\
\hline Suckers distance (area) (ns) & $301 \pm 85$ & $283 \pm 80$ \\
\hline
\end{tabular}

Measurements in mm; $a$ : significant to $5 \%$; ns: not significant.

\section{TABLE II}

Morphometric data (mean and standard deviation) of female adult worms of Schistosoma mansoni isolated from Nectomys squamipes ( $\mathrm{R}$ isolate) and humans ( $\mathrm{H}$ isolate)

\begin{tabular}{llcc}
\hline Character & & Isolates \\
\hline Eggs & & $\mathrm{H}(\mathrm{n}=51)$ & $\mathrm{R}(\mathrm{n}=48)$ \\
& area & $3225 \pm 690$ & $6495 \pm 2624$ \\
& longer axis & $100 \pm 11$ & $136 \pm 28$ \\
& smaller axis & $42 \pm 7$ & $60 \pm 16$ \\
& larger diameter & $97 \pm 13$ & $136 \pm 28$ \\
& shorter diameter & $39 \pm 8$ & $55 \pm 14$ \\
Spine & perimeter & $272 \pm 32$ & $378 \pm 80$ \\
& area & & $307 \pm 199$ \\
& larger diameter & $116 \pm 53$ & $26 \pm 9$ \\
& shorter diameter & $16 \pm 4$ & $12 \pm 5$ \\
puckers & perimeter & $8 \pm \pm 31$ \\
& oral (area) & $54 \pm 14$ & $2478 \pm 1124$ \\
ventral (area) & $1423 \pm 634$ & $2739 \pm 1343$ \\
\hline
\end{tabular}

Significant differences ( $\mathrm{p} £ 0.05$ ) in all characters; measurements in $\mathrm{mm}$. 


\section{DISCUSSION}

Biological studies on the compatibility between $S$. mansoni strains and their intermediate host, indicate that in the most compatible relationship the time required for the development in the snail host is shorter (Frandsen 1979, Paraense \& Corrêa 1981). Besides, cercariae produced have a greater capacity of infection (Zanotti-Magalhães et al. 1991).

Does such situation also occur in a vertebrate host? BH (Belo Horizonte, MG) strain of $S$. mansoni has adult male worms bigger than SJ (São José dos Campos, SP) strain and a better relationship with the snail host (Paraense \& Corrêa 1981). Some articles demonstrate this same aspect in the compatibility between a rodent strain and a invertebrate host (Bastos et al. 1979). In Brazil, there are few papers that describe the phenotypic characteristics of adult worms belonging to different strains (Magalhães \& Carvalho 1973, Paraense \& Corrêa 1981, Machado-Silva et al. 1995). Our data indicate that adult male worms ( $\mathrm{R}$ isolate) present smaller measurements than $\mathrm{H}$ isolate (Table I). However, this does not happen in adult female worms which have bigger measurements (Table II).

Supernumerary testes have been referred in several reports but the origin of this fact is unknown (Machado-Silva et al. 1995). This morphological feature was present in experimentally infected hosts (Vogel 1947, Najim 1951, Travassos 1953, Saoud 1965, Coles \& Thruston 1970, Soliman et al. 1984, Machado-Silva et al. 1995) as well as in a slyvatic rodent (Nectomys squamipes) harboring a natural infection (Machado-Silva et al. 1994). The number (six) of supernumerary testicular lobe found is higher than that found by other authors: one (Najim 1951, Saoud 1965, Coles \& Thruston 1970) or five (Travassos 1953).

In this article, besides traditional features (distance between suckers and size of the ova), we have applied other characteristics referred to trematodes helminths as taxonomic criteria (Kostandinova 1996, Roy \& Tandon 1993). In relation to the distance between suckers, our data (Table I) are in agreement with previous observations concerning these same samples recovered in swiss mice (Machado-Silva et al. 1995), but disagree with other researches that found significative differences between BH and SJ strains (Magalhães \& Carvalho 1973). According to data given in Table I, male adult worms display differences in several features related to the testicular lobes. These results add new data for previous studies that have found less morphological discrepancies among these same isolates (Machado-Silva et al. 1994).

Some reasons can justify the phenotypic dif- ferences seen in Schistosoma eggs: (i) location egg present in uterus are smaller than those passed in faeces (Saoud 1966); (ii) polymorphism - egg show morphometric differences in the shape according to the host (Kruger et al. 1986, Théron 1986). Our data regarding the shorter diameter of the eggs (Table II) are in accordance with observations made in female adult worms isolated from humans (Kastner et al. 1975). In this article, it was possible to ratify that eggs of Brazilian intra-specific variations exhibit significant morphometric differences (Table II). Besides, it was atested that such event does not occur exclusively in mature eggs passed in faeces (Paraense \& Corrêa 1981) but also in those imatures still located in the uterus. Only one egg present in the uterus is in agreement with other experiments conducted in Brazil (Magalhães \& Carvalho 1973, Kastner et al. 1975).

Data presented herein allow us to conclude that (i) sympatric isolates present morphometric differences, and (ii) morphological features in female worms is useful for proper identification of $S$. mansoni isolates.

\section{ACKNOWLEDGEMENTS}

To Dr Alexandre Ribeiro Bello, Departamento de Patologia e Laboratórios, Universidade do Estado do Rio de Janeiro, for English review.

\section{REFERENCES}

Barral V, This P, Imbert-Establet D, Combes C, Delseny M 1993. Genetic variability and evolution of Schistosoma mansoni genome analysed by using random amplified polymorphic DNA markers. Mol Biochem Parasitol 57: 211-222.

Bastos OC, Magalhães LA, Pareja GB 1979. Estudo da infecção experimental esquistossomótica produzida pelas linhagens humana e silvestre do Vale do rio Paraíba do Sul, SP (Brasil) em camundongos isogênicos. Rev Saúde públ S Paulo 13: 335-340.

Coles GC, Thurston JP 1970. Testes number in east african Schistosoma mansoni. J Helminthol 44: 6973.

Dias Neto E, Souza CP, Rollinson D, Katz N, Pena SDJ, Simpson AJG 1993. The random amplification of polymorphic DNA allows the identification of strains and species of schistosome. Mol Biochem Parasitol 57: 83-88.

Frandsen F 1979. Discussion of compatibility between Schistosoma and their intermatiate hosts, assessement of the degree of host-parasite compatibility and evaluation of schistosome taxonomy. $Z$ Parasitenkd 58: 275-296.

Kastner MRQ, Kohn A, Teixeira ED, Pitanga LC 1975. Estudo morfológico do Schistosoma mansoni Sambon, 1907 encontrado na espécie humana. Rev Soc Bras Med Trop 9: 247-261.

Kostandinova A 1966. Morphological variability of Brachylecithum microstesticulatum (Digenea: Dicroceliidae) in the Black Sea Region. Folia 
Parasitol 43: 47-51.

Kruger FJ, Schutte CHJ, Visser PS, Evans AC 1986. Phenotypic differences in Schistosoma mattheei ova from populations sympatric and allopatric of Schistosoma hematobium. Onderspoort J Vet Res 53: 103107.

Machado-Silva JR, Galvão C, Oliveira RMF, Presgrave OAF, Gomes DC 1995. Schistosoma mansoni: comparative morphological studies of some Brazilian strains. Rev Inst Med Trop São Paulo 37: 441-447.

Machado-Silva JR, Galvão C, Presgrave OAF, Rey L, Gomes DC 1994. Host induced morphological changes of Schistosoma mansoni Sambon, 1907 male worms. Mem Inst Oswaldo Cruz 89: 411-416.

Magalhães LA, Carvalho JF 1973. Estudo morfológico de Schistosoma mansoni pertencentes a linhagens de Belo Horizonte e de São José dos Campos (SP). Rev Saúde públ S Paulo 7: 289-294.

McManus DP, Hope M 1993. Molecular variation in human schistosomes. Acta Trop 53: 255-276.

Najim AT 1951. A male Schistosoma mansoni with two sets of testes. J Parasitol 37: 545-546.

Paraense WL, Corrêa LR 1981. Observations on two biological races of Schistosoma mansoni. Mem Inst Oswaldo Cruz 76: 287-291.

Pillay D, Pillay B 1994. Random amplified polymorphic DNA analysis shows intraspecies variation among Schistosoma mansoni isolates. Med Sci Res 22: 369-371.

Roy B, Tandon V 1993. Morphological and microtopo- graphical strain variations among Fasciolopsis buski originating from different geographical areas. Acta Parasitol 38: 72-77.

Saoud MFA 1965. Comparative studies on the characteristics of some geographical strains of Schistosoma mansoni in mice and hamsters. J Helminthol 39: 101112.

Saoud MFA 1966. On the morphology of Schistosoma rodhaini from Kenya. J Helminthol 40: 147-154.

Soliman GN, Mansour NS, El-Assal FM 1984. On the infraspecific variations in the frequency of supernumerary testes in Schistosoma mansoni. Z Parasitenkd 70: 561-564.

Théron A 1986. Polymorphisme des ouefs de Schistosoma mansoni dans le foyer Guadeloupéen (Antilhes Françaises): présence de "S. rodhaini-like" parasites? Acta Trop 43: 335-342.

Travassos L 1953. Algumas observações sobre a bionomia do Schistosoma mansoni Sambon, 1907, feitas na Cidade de Salvador. An Acad Bras Ciên 25: 157-163.

Vieira S 1991. Introdução à Bioestatística, Ed Campus, Rio de Janeiro, 203 pp.

Vogel H 1947. Hermaphrodites of Schistosoma mansoni. Ann Trop Med Parasit 41: 266-277.

Zannotti-Magalhães EM, Magalhães LA, Carvalho JF 1991. Relação entre a patogenicidade de Schistosoma mansoni em camundongos e a suscetibilidade do molusco vetor. 1 . Infecciosidade das cercárias e carga de vermes. Rev Saúde públ S Paulo 25: 359-366. 